\title{
ПОКАЗНИКИ ОКИСНЮВАЛЬНОГО СТРЕСУ В ЩУРІВ 3 ПАРАЦЕТАМОЛОВИМ ГЕПАТИТОМ ТА ЇХ КОРЕКЦІЯ ГУСТИМ ЕКСТРАКТОМ ІЗ ГРИБІВ МАЙТАКЕ
}

Вступ. У статmі наведено результати дослідження активності окиснювальних процесів і стану захисних систем щурів за умов ураження їх парацетамолом та після корекції густим екстрактом із грибів майтаке.

Мета дослідження - вивчити вплив густого екстракту з грибів майтаке на активність вільнорадикальних процесів та показники антиоксидантної системи за умов парацетамолового гепатиту в щурів.

Методи дослідження. Дослідження проводили на білих щурах-самцях. Тварин поділили на 10 груп, кожна з яких включала 6 щурів. Гострий гепатит моделювали шляхом інтрагастрального введення парацетамолу в дозі 1250 мг/кг 1 раз на добу (протягом 2 діб) у вигляді суспензії у 2 \% розчині крохмального гелю. Для корекції токсичного ураження застосовували густий екстракт із грибів майтаке, який вводили інтрагастрально за 2 год до введення парацетамолу та щоденно після ураження в дозі 150 мг/кг маси тіла. Препарат порівняння "Силібор" вводили за тією ж схемою, що і досліджуваний екстракт, у дозі 20 мг/кг маси тіла тварини. На 3-тю, 7-му та 10-ту доби від початку ураження здійснювали евтаназію щурів з використанням барбамілу натрію. Дослідженням піддавали гомогенат печінки та сироватку крові. Активність процесів вільнорадикального окиснення при парацетамоловому гепатиті й після введення коригувальних препаратів оцінювали за активністю супероксиддисмутази і каталази, вмістом ТБК-активних продуктів та продуктів окиснювальної модифрікації протеїнів.

Результати й обговорення. Про підвищення активності процесів вільнорадикального окиснення після ураження щурів парацетамолом свідчили зниження активності супероксиддисмутази і каталази, підвищення вмісту ТБК-активних продуктів, продуктів окиснювальної модифрікації протеїнів нейтрального й основного характеру в сироватці крові та печінці тварин. Експериментально доведено ефективність застосування густого екстракту з грибів майтаке і його позитивний вплив на активність процесів ліпопероксидації та окиснювальної модифрікації протеїнів за умов парацетамолового гепатиту в щурів.

Висновок. Застосування досліджуваного екстракту з грибів майтаке за умов змодельованого гострого гепатиту в щурів привело до нормалізації показників ліпопероксидації, окиснювальної модифікації протеїнів та антиоксидантного захисту.

КЛЮЧОВІ СЛОВА: гриби майтаке; парацетамол; гепатит; густий екстракт; окиснювальний стрес; антиоксидантні властивості.

ВСТУП. Окиснювально-відновні реакції лежать в основі метаболічних процесів людини, але надмірна активація вільнорадикального окиснення може призвести до цілого ряду негативних реакцій, що в подальшому викликає низку захворювань, зокрема ішемічну хворобу серця, атеросклероз, артеріальну гіпертензію, гепатит, цукровий діабет та багато інших серйозних патологій $[1,2]$.

Експериментально підтверджено, що багато лікарських рослин, а також гриби проявляють антиоксидантну дію та чинять мінімальний побічний вплив на організм людини $[1,3,4]$. Створення нових високоактивних, малотоксичних біологічно активних речовин спрямованої дії $\epsilon$ актуальною проблемою сучасної фрармації, яка (с) І. І. Герасимець, Л. С. Фіра, І. І. Медвідь, 2020. на даний час потребує чіткого алгоритму. Саме тому для досліджень ми обрали гриби майтаке (Grifola frondosa), які незаперечно проявляють корисні властивості, адже до їх складу входить багато мінералів і вітамінів, що робить доцільним споживання цих грибів, особливо людьми 3 ослабленим імунітетом. Численні дослідження підтверджують позитивний вплив грибів на здоров'я людей, які мають гепатит, цукровий діабет, серцеві захворювання, страждають від головного болю чи застуди [5-7].

У країнах Азії Grifola frondosa широко використовують як природний лікарський засіб, лікарі й натуропати рекомендують їх для підтримувального впливу на імунну систему $[8,9]$.

Мета дослідження - вивчити вплив густого екстракту з грибів майтаке на активність вільно- 
радикальних процесів та показники антиоксидантної системи за умов парацетамолового гепатиту в щурів.

МЕТОДИ ДОСЛІДЖЕННЯ. Матеріалом для проведення експериментів слугував густий екстракт із грибів майтаке (ГЕГМ), який виготовили і надали для досліджень співробітники кафредри хімії природних сполук Національного фрармацевтичного університету та який було стандартизовано за стероїдними сполуками відповідно до вимог ДФУ.

Дослідження проводили на 60 білих щурахсамцях масою 180-210 г, яких утримували на стандартному раціоні віварію Тернопільського національного медичного університету імені І. Я. Горбачевського МОЗ України з дотриманням правил біоетики відповідно до Європейської конвенції про захист хребетних тварин, що використовуються для дослідних та інших наукових цілей [10].

Гострий гепатит моделювали шляхом інтрагастрального введення парацетамолу в дозі 1250 мг/кг 1 раз на добу (протягом 2 діб) у вигляді суспензії у 2 \% розчині крохмального гелю. Для корекції токсичного ураження застосовували густий екстракт із грибів майтаке, який вводили інтрагастрально за 2 год до введення токсиканта і щоденно після ураження в дозі 150 мг/кг маси тіла. Препарат порівняння "Силібор" вводили за тією ж схемою, що й екстракт із грибів майтаке, в дозі 20 мг/кг маси тіла тварини.

Щурів поділили на 10 груп, кожна з яких включала 6 тварин: 1-ша - тварини інтактного контролю; 2-га, 3-тя і 4-та - щури, отруєні парацетамолом, 3-тя, 7-ма та 10-та доби дослідження відповідно; 5-та, 6-та і 7-ма - уражені тварини, яким вводили екстракт із грибів майтаке в дозі 150 мг/кг маси тіла, 3-тя, 7-ма та 10-та доби експерименту відповідно; 8-ма, 9-та і 10-та уражені щури, яким інтрагастрально вводили препарат "Силібор”, 3-тя, 7-ма та 10-та доби дослідження відповідно.
На 3-тю, 7-му та 10-ту доби від початку ураження здійснювали евтаназію тварин з використанням барбамілу натрію. Дослідженням піддавали гомогенат печінки та сироватку крові. Кров забирали із серця тварин. Активність процесів вільнорадикального окиснення за умов ураження щурів парацетамолом і після введення коригувальних чинників оцінювали за вмістом ТБК-активних продуктів (ТБК-АП) [2] та продуктів окиснювальної модифікації протеїнів [11, 12], стан антиоксидантної системи - за активністю супероксиддисмутази (СОД) [13] і каталази (Кат) [14].

Отримані результати піддавали статистичній обробці в програмі STATISTICA 12. Достовірність міжгрупових відмінностей визначали за допомогою критерію рангових сум Вілкоксона та критерію Манна - Уїтні. Результати вважали достовірними при $\mathrm{p} \leq 0,05[15,16]$.

РЕЗУЛЬТАТИ Й ОБГОВОРЕННЯ. ПіД ЧАС аналізу результатів біохімічних досліджень було встановлено, що ураження щурів парацетамолом призводить до підвищення інтенсивності процесів вільнорадикального окиснення, зокрема ліпопероксидації.

Ми дослідили вміст ТБК-АП, які $є$ одним із кінцевих показників пероксидного окиснення ліпідів, у сироватці крові та печінці тварин з гострим гепатитом. Після ураження щурів парацетамолом різко зростав їх вміст у вищевказаних тканинах (табл. 1).

На 3-тю добу від початку ураження вміст ТБК-АП підвищився у 2,2 раза у сироватці крові та в 1,5 раза в печінці тварин порівняно $з$ контролем. На 7-му та 10-ту доби експерименту величина цього показника зростала і була більшою від такої в інтактних тварин у 2,6 та 1,7 раза у сироватці крові й у 2,7 і 1,7 раза в печінці щурів відповідно. Застосування як коригувального чинника ГЕГМ викликало достовірне зниження вмісту ТБК-АП як у сироватці крові, так і в печінці щурів з парацетамоловим гепатитом уже на

Таблиця 1 - Вміст ТБК-активних продуктів у сироватці крові (мкмольл) та печінці (мкмоль/кг) щурів, уражених парацетамолом, і після застосування екстракту з грибів майтаке $(M \pm m, n=60)$

\begin{tabular}{||l|c|c|c|c|c|c||}
\hline \multirow{2}{*}{$\begin{array}{c}\text { Група } \\
\text { тварин }\end{array}$} & \multicolumn{9}{c||}{ Показник } \\
\cline { 2 - 7 } & \multicolumn{2}{|c|}{ 3-тя доба } & \multicolumn{2}{c||}{ 7-ма доба } & \multicolumn{2}{c||}{ 10-та доба } \\
\cline { 2 - 7 } & кров & печінка & кров & печінка & кров & печінка \\
\hline IК & $2,91 \pm 0,32$ & $16,77 \pm 0,68$ & $2,91 \pm 0,32$ & $16,77 \pm 0,68$ & $2,91 \pm 0,32$ & $16,77 \pm 0,68$ \\
\hline КП & $6,51 \pm 0,37^{*}$ & $25,03 \pm 0,94^{*}$ & $7,62 \pm 0,29^{\star}$ & $27,72 \pm 0,91^{\star}$ & $7,97 \pm 0,25^{\star}$ & $28,77 \pm 1,20^{\star}$ \\
\hline КП+силібор & $4,75 \pm 0,25^{\star \star}$ & $21,32 \pm 0,96^{\star \star}$ & $5,33 \pm 0,56^{\star \star}$ & $22,20 \pm 1,05^{\star \star}$ & $4,88 \pm 0,35^{\star \star}$ & $23,11 \pm 1,08^{\star \star}$ \\
\hline КП+ГЕГМ & $4,38 \pm 0,22^{\star \star}$ & $20,59 \pm 0,59^{\star \star}$ & $5,56 \pm 0,39^{\star \star}$ & $22,78 \pm 0,78^{\star \star}$ & $4,56 \pm 0,32^{\star \star}$ & $22,04 \pm 0,23^{\star \star}$ \\
\hline \hline
\end{tabular}

Примітки. Тут, у таблицях 2-4 і на рисунку:

1. ІК - інтактний контроль; КП - контрольна патологія.

2. * - достовірні зміни між показниками контрольних та уражених парацетамолом щурів; ** - достовірні зміни між показниками уражених парацетамолом і лікованих тварин. 
3-тю добу дослідження порівняно з групою контрольної патології.

Препарат порівняння "Силібор" також спричиняв достовірне зменшення вмісту ТБК-АП у сироватці крові та печінці тварин, уражених парацетамолом, уже на 3-тю добу експерименту.

Про розвиток окиснювального стресу свідчило зростання вмісту продуктів окиснювальної модифрікації протеїнів у сироватці крові та печінці тварин $з$ парацетамоловим гепатитом. Це, очевидно, пов'язано з надлишковим утворенням вільних радикалів та активних фоорм оксигену через ушкодження гепатоцитів токсикантом.

При дослідженні показників окиснювальної модифрікації протеїнів встановлено, що у сироватці крові та печінці щурів з парацетамоловим гепатитом достовірно підвищувався вміст 2,4-динітрофенілгідразонів (2,4-ДНФГ) нейтрального (370 нм) й основного характеру (430 нм) протягом усього експерименту (табл. 2, 3).

На 3-тю добу дослідження вміст 2,4-ДНФГ нейтрального характеру збільшився у 2,5 раза у сироватці крові та в 1,6 раза в печінці щурів 3 токсичним гепатитом. На 7-му та 10-ту доби експерименту спостерігали аналогічну тенденцію до підвищення цього показника.

Як видно з таблиці 2, вміст 2,4-ДНФГ нейтрального характеру достовірно зменшився як у сироватці крові, так і в печінці тварин, уражених парацетамолом, після застосування ГЕГМ. Аналогічне зниження цього показника у досліджуваних тканинах відзначали після застосування силібору.

При вивченні вмісту 2,4-ДНФГ основного характеру відмічено достовірне його збільшення на 3-тю добу експерименту в 3,5 і 2,2 раза у сироватці крові та печінці щурів з парацетамоловим ураженням печінки порівняно з інтактними тваринами (табл. 3). На 7-му добу цей показник підвищився в 4,8 раза у сироватці крові та у 2,6 раза в печінці щурів 3 гепатитом відносно контролю. На 10-ту добу дослідження спостерігали ще більше зростання вмісту 2,4-ДНФГ основного характеру в групі контрольної патології порівняно з інтактними тваринами.

Під впливом ГЕГМ вміст 2,4-ДНФГ основного характеру достовірно знижувався у сироватці крові та печінці щурів порівняно з групою тварин, яким не проводили корекції. Силібор також проявив позитивний вплив на цей показник, проте він був менш ефрективним, ніж досліджуваний екстракт.

На противагу вільнорадикальним процесам в організмі існує антиоксидантна система, представлена перш за все системою антиоксидантних ензимів: супероксиддисмутазою, що зв'язує активні фрорми оксигену з утворенням пероксиду гідрогену; каталазою, яка деструктурує перекиси в ліпідні гідропероксиди; глутатіонпероксидазою, що редукує ліпідні гідропероксиди за рахунок окиснення глутатіону; глутатіонредуктазою, яка відновлює глутатіон шляхом окиснення НАДФН, останній відновлюється через цитохромний ланцюг і систему природних антиоксидантів (а-токоферол, аскорбінова кислота, фрлавоноїди) $[17,18]$.

За умов парацетамолового гепатиту досліджено активність СОД, яка є ключовим ензимом антирадикального захисту. Про ураження антиоксидантної системи організму щурів після введення токсиканта свідчило значне зниження активності СОД у сироватці крові та печінці тва-

Таблиця 2 - Вміст 2,4-динітрофенілгідразонів нейтрального характеру (мкмоль/г протеїну) в сироватці крові та печінці щурів, уражених парацетамолом, і після застосування екстракту з грибів майтаке ( $\mathrm{M} \pm \mathrm{m}, \mathrm{n}=60)$

\begin{tabular}{|c|c|c|c|c|c|c|}
\hline \multirow{3}{*}{$\begin{array}{c}\text { Група } \\
\text { тварин }\end{array}$} & \multicolumn{6}{|c|}{ Показник } \\
\hline & \multicolumn{2}{|c|}{ 3-тя доба } & \multicolumn{2}{|c|}{ 7-ма доба } & \multicolumn{2}{|c|}{ 10-та доба } \\
\hline & кров & печінка & кров & печінка & кров & печінка \\
\hline IK & $0,032 \pm 0,005$ & $0,075 \pm 0,005$ & $0,032 \pm 0,005$ & $0,075 \pm 0,005$ & $0,032 \pm 0,005$ & $0,075 \pm 0,005$ \\
\hline КП & $0,079 \pm 0,007^{*}$ & $0,121 \pm 0,007^{*}$ & $0,089 \pm 0,005^{\star}$ & $0,137 \pm 0,007^{*}$ & $0,095 \pm 0,004^{*}$ & $0,148 \pm 0,007^{*}$ \\
\hline КП+силібор & $0,060 \pm 0,008$ & $0,101 \pm 0,006$ & $0,061 \pm 0,006^{\star \star}$ & $0,100 \pm 0,007^{\star *}$ & $0,050 \pm 0,005^{\star \star}$ & $0,103 \pm 0,005^{\star \star}$ \\
\hline КП+ГЕГМ & $0,056 \pm 0,008$ & $0,106 \pm 0,009$ & $0,053 \pm 0,006^{\star \star}$ & $0,088 \pm 0,010^{\star *}$ & $0,047 \pm 0,003^{\star \star}$ & $0,083 \pm 0,010^{\star \star}$ \\
\hline
\end{tabular}

Таблиця 3 - Вміст 2,4-динітрофенілгідразонів основного характеру (мкмоль/г протеїну) в сироватці крові та печінці щурів, уражених парацетамолом, і після застосування екстракту з грибів майтаке (M $\pm m, n=60)$

\begin{tabular}{||l|c|c|c|c|c|c||}
\hline \multirow{2}{*}{$\begin{array}{c}\text { Группа } \\
\text { тварин }\end{array}$} & \multicolumn{9}{|c|}{ Показник } \\
\cline { 2 - 7 } & \multicolumn{2}{|c|}{ 3-тя доба } & \multicolumn{2}{c|}{ 7-ма доба } & \multicolumn{2}{c|}{ 10-та доба } \\
\cline { 2 - 7 } & кров & печінка & кров & печінка & кров & печінка \\
\hline IК & $0,011 \pm 0,002$ & $0,037 \pm 0,003$ & $0,011 \pm 0,002$ & $0,037 \pm 0,003$ & $0,011 \pm 0,002$ & $0,037 \pm 0,003$ \\
\hline КП & $0,039 \pm 0,005^{\star}$ & $0,080 \pm 0,004^{*}$ & $0,053 \pm 0,005^{\star}$ & $0,095 \pm 0,008^{\star}$ & $0,063 \pm 0,004^{\star}$ & $0,104 \pm 0,009^{\star}$ \\
\hline КП+силібор & $0,034 \pm 0,003$ & $0,067 \pm 0,006$ & $0,035 \pm 0,004^{\star \star}$ & $0,054 \pm 0,004^{\star \star}$ & $0,032 \pm 0,003^{\star \star}$ & $0,052 \pm 0,005^{\star \star}$ \\
\hline КП+ГЕГМ & $0,029 \pm 0,004$ & $0,063 \pm 0,006^{\star \star}$ & $0,029 \pm 0,004^{\star \star}$ & $0,049 \pm 0,006^{\star \star}$ & $0,025 \pm 0,005^{\star \star}$ & $0,046 \pm 0,004^{\star \star}$ \\
\hline \hline
\end{tabular}


рин відносно контролю, що може бути викликано підвищенням концентрації пероксиду гідрогену та накопиченням сполук, які можуть впливати на ступінь відновлення ензиму (рис.).

Введення в уражений організм густого екстракту з грибів майтаке привело до достовірного підвищення активності СОД у сироватці крові вже на 3-тю добу експерименту - в 1,1 раза відносно групи контрольної патології. При дослідженні впливу ГЕГМ на активність СОД у печінці тварин з гепатитом встановлено, що достовірно активність ензиму зросла в 1,2 раза відносно уражених щурів на 7-му добу експерименту. Корекція препаратом порівняння "Силібор" також проявила позитивний вплив на активність СОД.

Введення токсиканта викликало зниження активності Кат у сироватці крові та печінці тварин (табл. 4). На 3-тю добу після ураження активність ензиму в сироватці крові зменшилась на $61 \%$, на 7-му - на $64 \%$, на 10-ту - на $68 \%$ порівняно 3 контролем. Активність Кат у печінці щурів під впливом парацетамолу знизилась на 55, 57 і 60 \% на 3-тю, 7-му та 10-ту доби дослідження відповідно відносно інтактних тварин.

Після корекції ГЕГМ спостерігали позитивну динаміку щодо активності Кат, яка вже на 7-му добу експерименту підвищилась у 2,1 раза в сироватці крові та в 1,8 раза в печінці тварин відносно групи контрольної патології. Після за- стосування препарату порівняння "Силібор" відмічено достовірне зростання активності ензиму на 7-му добу дослідження - в 1,8 раза у сироватці крові та в 1,6 раза в печінці щурів відносно тварин з парацетамоловим гепатитом.

ВИСНОВКИ. 1. Результати досліджень дозволяють стверджувати, що ураження печінки парацетамолом призводить до інтенсиорікації процесів вільнорадикального окиснення, що підтверджується активацією процесів ліпопероксидації та окиснювальної модисрікації протеїнів. Про це свідчать підвищення вмісту ТБК-активних продуктів та 2,4-динітрофенілгідразонів, зниження активності супероксиддисмутази і каталази у сироватці крові й печінці тварин 3 парацетамоловим гепатитом.

2. Густий екстракт із грибів майтаке проявив ефективний коригувальний вплив на показники ліпопероксидації та окиснювальної модифрікації протеїнів, наближаючи їх до таких у тварин інтактного контролю. Відмічено позитивний вплив екстракту на показники антиоксидантної системи, зокрема його застосування привело до відновлення активності супероксиддисмутази і каталази.

3. Введення препарату порівняння "Силібор" викликало достовірне зниження вмісту ТБК-активних продуктів, 2,4-динітрофенілгідразонів

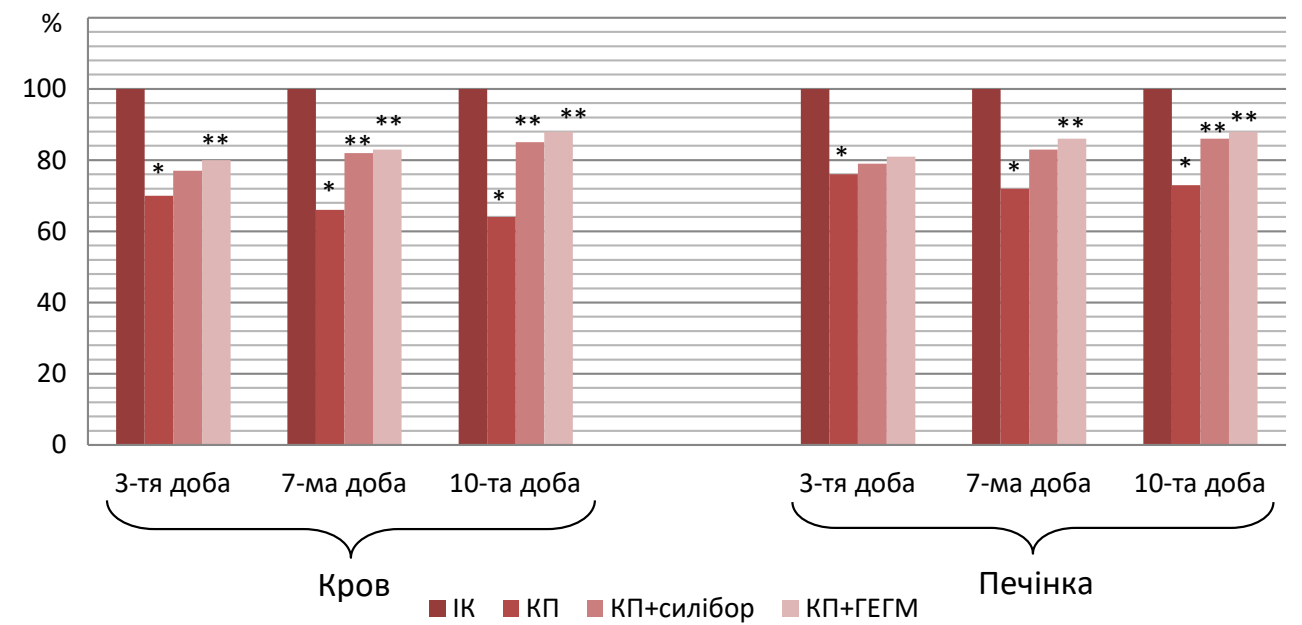

Рис. Активність супероксиддисмутази у сироватці крові та печінці щурів, уражених парацетамолом, і після застосування екстракту з грибів майтаке, \%.

Таблиця 4 - Активність каталази у сироватці крові (мкат/л) та печінці (мкат/кг) щурів, уражених

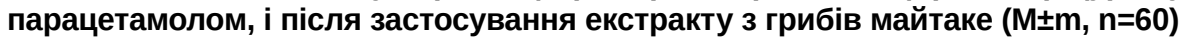

\begin{tabular}{|l|c|c|c|c|c|c||}
\hline \multirow{2}{*}{ Група тварин } & \multicolumn{9}{|c|}{ Показник } \\
\cline { 2 - 7 } & \multicolumn{2}{|c|}{ 3-тя доба } & \multicolumn{2}{c||}{ 7-ма доба } & \multicolumn{2}{c||}{ 10-та доба } \\
\cline { 2 - 7 } & кров & печінка & кров & печінка & кров & печінка \\
\hline ІК & $4,43 \pm 0,36$ & $7,16 \pm 0,22$ & $4,43 \pm 0,36$ & $7,16 \pm 0,22$ & $4,43 \pm 0,36$ & $7,16 \pm 0,22$ \\
\hline КП & $1,71 \pm 0,17^{\star}$ & $3,24 \pm 0,31^{*}$ & $1,60 \pm 0,11^{\star}$ & $3,05 \pm 0,28^{\star}$ & $1,41 \pm 0,18^{\star}$ & $2,86 \pm 0,36^{\star}$ \\
\hline КП+силібор & $2,03 \pm 0,26$ & $4,20 \pm 0,30$ & $2,90 \pm 0,26^{\star \star}$ & $4,94 \pm 0,39^{\star \star}$ & $3,11 \pm 0,18^{\star \star}$ & $5,54 \pm 0,50^{\star \star}$ \\
\hline КП+ГЕГМ & $2,35 \pm 0,54$ & $4,73 \pm 0,20^{\star \star}$ & $3,28 \pm 0,20^{\star \star}$ & $5,53 \pm 0,37^{\star \star}$ & $3,24 \pm 0,16^{\star \star}$ & $5,99 \pm 0,36^{\star \star}$ \\
\hline
\end{tabular}


нейтрального й основного характеру, підвищення активності супероксиддисмутази і каталази у сироватці крові та печінці тварин порівняно 3 групою контрольної патології. Проте вплив силібору на вищевказані показники був менш ефективним, ніж густого екстракту з грибів майтаке.

\section{СПИСОК ЛІТЕРАТУРИ}

1. Медвідь І. І. Показники антиоксидантної системи щурів, уражених тетрахлорметаном, після застосування екстракту з листя шовковиці / І. І. Медвідь, Л. С. Фіра, Н. І. Бурмас // Мед. хімія. - 2011. - 13, № 4 (49). - С. 54-56.

2. Лущак В. І. Показники оксидативного стресу. Тіобарбітурактивні продукти і карбонільні групи білків / В. І. Лущак, Т. В. Багнюкова, О. В. Лущак // Укр. біохім. журн. - 2004. - 26. - С. 136-141.

3. Медвідь І. І. Вивчення гіпоглікемічної дії $40 \%$ настойки 3 листя шовковиці в умовах алоксанового діабету у щурів / І. І. Медвідь, Л. С. Фіра // Здобутки клініч. та експерим. медицини. - 2011. - № 2 (13). C. 85-88.

4. Antioxidant properties and antioxidant compounds of various extracts from the edible basidiomycete Grifola frondosa (Maitake) / J. Y. Yeh, L. H. Hsieh, K. T. Wu, C. F. Tsai // Molecules (Basel, Switzerland). - 2011. - 16 (4). - P. 3197-3211. DOI:10.3390/molecules16043197. - Access mode : https://www.ncbi.nlm.nih. gov/pmc/articles/PMC6260640/.

5. Герасимець І. І. Вивчення умовно терапевтичної дози густого екстракту з грибів майтаке / I. І. Герасимець, Л. С. Фіра, І. І. Медвідь // Colloquium-journal. Warszawa, Poland. - 2020. - № 13 (65). - C. 5-9.

6. Maitake Pro4X has anti-cancer activity and prevents oncogenesis in BALBc mice /A. Roldan-Deamicis, E. Alonso, B. Brie [et al.] // Cancer Medicine. - 2016. 5 (9). - P. 2427-2441. -Access mode : https://www.ncbi. nlm.nih.gov/pmc/articles/PMC5055164/.

7. The mechanisms underlying the hypolipidaemic effects of Grifola frondosa in the liver of rats / Y. Ding, C. Xiao, Q. Wu [et al.] // Frontiers in Microbiology. 2016. - 7. - P. 1186. DOI:10.3389/fmicb.2016.01186. Access mode : https://www.ncbi.nlm.nih.gov/pmc/articles/ PMC4971090/.

8. Grifola frondosa polysaccharides induce breast cancer cell apoptosis via the mitochondrial-dependent apoptotic pathway / Y. Zhang, D. Sun, Q. Meng [et al.] // International Journal of Molecular Medicine. - 2017. 40 (4). - P. 1089-1095. - Access mode : https://www. ncbi.nlm.nih.gov/pmc/articles/PMC5593468/.

\section{REFERENCES}

1. Medvid, I.I., Fira, L.S., \& Burmas, N.I. (2011). Pokaznyky antyoksydantnoi systemy shchuriv, urazhenykh tetrakhlormetanom, pislia zastosuvannia ekstraktu z lystia shovkovytsi [Indicators of the antioxidant system of rats affected by carbon tetrachloride after application of mulberry leaf extract]. Medychna khimiia - Medical Chemistry, 13, 4 (49), 54-56 [in Ukrainian].
9. Vetvicka V. Immune-enhancing effects of Maitake (Grifola frondosa) and Shiitake (Lentinula edodes) extracts / V. Vetvicka, J. Vetvickova // Annals of Translational Medicine. - 2014. - 2 (2). - P. 14. -Access mode : https://www.ncbi.nlm.nih.gov/pmc/articles/PMC4202470/.

10. Gross D. Ethics in Animal-Based Research / D. Gross, R. Tolba // Eur. Surg. Res. - 2015. - 55, No. 1-2. - P. 43-57. [PubMed].

11. Дубинина Е. Е. Окислительный стресс и окислительная модификация белков / Е. Е. Дубинина // Med. Chemistry. - 2001. - 2. - C. 5-12.

12. Дубинина Е. Е. Роль активных форм кислорода в качестве сигнальных молекул в метаболизме тканей при состоянии окислительного стресса / Е. Е. Дубинина // Вопр. мед. хим. - 2001. -47, № 6. C. 561-581.

13. Babizhayev M. A. Mitochondria induce oxidative stress, generation of reactive oxygen species and redox state unbalance of the eye lens leading to human formation: disruption of redox lens organization by phispholipid hydroperoxides / M. A. Babizhayev // Cell Biochem. Funct. - 2011. - 29 (3). - P. 183-206. DOI: 10.1002/ cbf.1737.

14. Королюк М. А. Метод определения активности каталазы / М. А. Королюк, Л. И. Иванова, И. Г. Майорова // Лаб. дело. - 1988. - № 1. - С. 16-19.

15. Шеламова М. А. Статистический анализ медико-биологических данных с использованием программы EXCEL / M. А. Шеламова, Н. И. Инсарова, В. Г. Лещенко. - Минск : БГМУ, 2010. - 96 с.

16. Citation bias favoring statistically significant studies was present in medical research / A. S. Jannot, T. Agoritsas, A. Gayet-Ageron [et al.] // J. Clin. Epidemiol. 2013. - No. 66 (3). - P. 296-301. DOI:10.1016/j. jclinepi.2012.09.015.

17. Лозова Т. М. Антиоксидантні властивості інноваційних інгредієнтів для харчових продуктів / Т. М. Лозова // Вісн. Львівського торговельно-економічного ун-ту. - 2016. - Вип. 17. - С. 79-83.

18. Karabulut I. Effect of $\alpha$-tocopherol, $\beta$-carotene and ascorbul palmitate on oxidative stability of butter oil triacylgcerols / I. Karabulut // Food Chem. - 2014. 123, No. 3. - P. 622-627.

2. Lushchak, V.I., Bahniukova, T.V., \& Lushchak, O.V. (2004). Pokaznyky oksudatyvnoho stresu. Tiobarbituraktyvni produkty i karbonilni hrupy bilkiv [Indicators of oxidative stress. Thiobarbiturative products and carbonyl groups of proteins ]. Ukrainskyi biokhimichnyi zurnal Ukrainian Biochemical Journal, 26, 136-141 [in Ukrainian]. 
3. Medvid, I.I., \& Fira, L.S. (2011). Vyvchennia hipohlikemichnoi dii $40 \%$ nastoiky z lystia shovkovytsi v umovakh aloksanovoho diabetu u shchuriv [Study of the hypoglycemic effect of $40 \%$ tincture of mulberry leaves in alloxan diabetes in rats]. Zdobutky klinichnoi ta eksperymentalnoi medytsyny - Achievements of Clinical and Experimental Medicine, 2 (13), 85-88 [in Ukrainian].

4. Yeh, J.Y., Hsieh, L.H., Wu, K.T., \& Tsai, C.F. (2011). Antioxidant properties and antioxidant compounds of various extracts from the edible basidiomycete Grifola frondosa (Maitake). Molecules (Basel, Switzerland), 16 (4), 3197-211. DOI: 10.3390/molecules16043197. Retrieved from: https://www.ncbi.nlm.nih.gov/pmc/articles/ PMC6260640/

5. Herasymets, I.I., Fira, L.S., \& Medvid, I.I. (2020). Vyvchennia umovno terapevtuchnoi dozy hustoho ekstraktu z hrybiv maitake [Study of the conditionally therapeutic dose of a thick extract of Maitake mushrooms] Colloquium-journal, Warszawa, Poland, 13 (65), 5-9. DOI: 10.24411/2520-6990-2020-11853 [in Ukrainian].

6. Roldan-Deamicis, A., Alonso, E., Brie, B., Braico, D.A., \& Balogh, G.A. (2016). Maitake Pro4X has anti-cancer activity and prevents oncogenesis in BALBC mice. Cancer Medicine, 5 (9), 2427-2441. Retrieved from: https://www.ncbi.nlm.nih.gov/pmc/articles/PMC5055164/

7. Ding, Y., Xiao, C., Wu, Q., Xie, Y., Li, X., Hu, H., \& Li, L. (2016). The mechanisms underlying the hypolipidaemic effects of Grifola frondosa in the liver of rats. Frontiers in Microbiology, 7, 1186. DOI:10.3389/ fmicb.2016.01186. Retrieved from: https://www.ncbi.nlm. nih.gov/pmc/articles/PMC4971090/.

8. Zhang, Y., Sun, D., Meng, Q., Guo, W., Chen, Q. \& Zhang, Y. (2017). Grifola frondosa polysaccharides induce breast cancer cell apoptosis via the mitochondrialdependent apoptotic pathway. International Journal of Molecular Medicine, 40 (4), 1089-1095. Retrieved from: https://www.ncbi.nlm.nih.gov/pmc/articles/PMC5593468/.

9. Vetvicka, V., \& Vetvickova, J. (2014). Immuneenhancing effects of Maitake (Grifola frondosa) and Shiitake (Lentinula edodes) extracts. Annals of Translational Medicine, 2 (2), 14. Retrieved from: https://www. ncbi.nlm.nih.gov/pmc/articles/PMC4202470/.
10. Gross, D., \& Tolba, R. (2015). Ethics in animalbased research. Eur. Surg. Res., 55, 1-2, 43-57 [PubMed].

11. Dybinina, Ye.Ye. (2001). Okislityelnyy stress i okislityelnaya modifikatsiya belkov [Oxidative stress and oxidative modification of proteins]. Med. Chemistry, 2, 5-12 [in Russian].

12. Dybinina, Ye.Ye. (2001). Rol aktivnykh form kisloroda $v$ kachestvye signalnykh molekul $v$ metabolizmye tkanyey pri sostoyanii okislityelnoho stressa [Role of reactive oxygen species as signaling molecules in tissue metabolism in a state of oxidative stress]. Voprosy meditsinskoy khimii - Issues of Medical Chemistry, 47 (6), 561-581 [in Russian].

13. Babizhayev, M.A. (2011). Mitochondria induce oxidative stress, generation of reactive oxygen species and redox state unbalance of the eye lens leading to human formation: disruption of redox lens organization by phispholipid hydroperoxides. Cell Biochem. Funct., 29 (3), 183-206. DOI: 10.1002/cbf.1737.

14. Korolyuk, M.A., Ivanova, L.I., \& Mayorova, I.G. (1988). Metod opryedileniya aktivnosti katalazy [Method for the catalase activity determination]. Laboratornoye delo - Laboratoty Work, 1, 16-19 [in Russian].

15. Shelamova, M.A., Insarova, N.I., \& Lyeshchyenko, V.H. (2010). Statisticheskiy analiz mediko-biologichyeskikh dannykh s ispolzovaniyem programmy EXCEL [Statistical analysis of biomedical data using the EXCEL program]. Minsk: BGMU [in Russian].

16. Jannot, A.S., Agoritsas, T.A., \& Gayet-Ageron, A. (2013). Citation bias favoring statistically significant studies was present in medical research. J. Clin. Epidemiol., 66 (3), 296-301. DOI:10.1016/j.jclinepi.2012.09.015.

17. Lozova, T.M. (2016). Antyoksydantni vlastyvosti innovatsiinykh inhrediientiv dlia kharchovykh produktiv [Antioxidant properties of innovative ingredients for food]. Visnyk Lvivskoho torhovelno-ekonomichnoho universytetu - Bulletin of Lviv Trade Economic University, 17, 79-83 [in Ukrainian].

18. Karabulut, I. (2014). Effect of $\alpha$-tocopherol, $\beta$-carotene and ascorbul palmitate on oxidative stability of butter oil triacylgcerols. Food Chem., 123 (3), 622-627.

И. И. Герасимец, Л. С. Фира, И. И. Медвидь ТЕРНОПОЛЬСКИЙ НАЦИОНАЛЬНЫЙ МЕДИЦИНСКИЙ УНИВЕРСИТЕТ ИМЕНИ И. Я. ГОРБАЧЕВСКОГО МОЗ УКРАИНЫ

\section{ПОКАЗАТЕЛИ ОКИСЛИТЕЛЬНОГО СТРЕССА У КРЫС С ПАРАЦЕТАМОЛОВЫМ ГЕПАТИТОМ И ИХ КОРРЕКЦИЯ ГУСТЫМ ЭКСТРАКТОМ ИЗ ГРИБОВ МАЙТАКЕ}

\section{Резюме}

Вступление. В статье приведены результаты исследования активности окислительных процессов и состояния защитных систем крыс в условиях поражения их парацетамолом и после коррекции густым экстрактом из грибов майтаке.

Цель исследования - изучить влияние густого экстракта из грибов майтаке на активность свободнорадикальных процессов и показатели антиоксидантной системы в условиях парацетамолового гепатита у крыс.

Методы исследования. Исследования проводили на белых крысах-самцах. Животных разделили на 10 групп, каждая из которых включала 6 животных. Острый гепатит моделировали путем интрагастрального введения парацетамола в дозе 1250 мг/кг 1 раз в сутки (в течение 2 суток) в виде суспензии в 2 \% растворе крахмального геля. Для коррекции токсического поражения применяли густой экстракт из грибов майтаке, который вводили интрагастрально за 2 ч до введения парацетамола и ежедневно 
после поражения в дозе 150 мг/ка массы тела. Препарат сравнения “Силибор" вводили по той же схеме, что и исследуемый екстракт, в дозе 20 мг/кг массы тела животного. На 3-е, 7-е и 10-е сутки от начала поражения осуществляли эвтаназию крыс с использованием барбамила натрия. Исследованиям подвергали гомогенат печени и сыворотку крови. Активность процессов свободнорадикального окисления при парацетамоловом гепатите и после введения корректирующих препаратов оценивали по активности супероксиддисмутазы, каталазы, содержанию ТБК-активных продуктов и продуктов окислительной модифрикации протеинов.

Результаты и обсуждение. О повышении активности процессов свободнорадикального окисления после поражения крыс парацетамолом свидетельствовали снижение активности супероксиддисмутазы и каталазы, повышение содержания ТБК-активных продуктов, продуктов окислительной модификации протеинов нейтрального и основного характера в сыворотке крови и печени животных. Экспериментально доказаны эфрфективность применения густого экстракта из грибов майтаке и его положительное влияние на активность процессов липопероксидации и окислительной модифрикации протеинов в условиях парацетамолового гепатита у крыс.

Вывод. Применение исследуемого экстракта из грибов майтаке в условиях смоделированного острого гепатита у крыс привело к нормализации показателей липопероксидации, окислительной модифрикации протеинов и антиоксидантной защиты.

КЛЮЧЕВЫЕ СЛОВА: грибы майтаке; парацетамол; гепатит; густой экстракт; окислительный стресс; антиоксидантные свойства.

I. I. Herasymets, L. S. Fira, I. I. Medvid

I. HORBACHEVSKY TERNOPIL NATIONAL MEDICAL UNIVERSITY

\section{INDICATORS OF OXIDATIVE STRESS IN RATS WITH PARACETAMOL HEPATITIS AND CORRECTION WITH A DENSE EXTRACT FROM MAITAKE MUSHROOMS}

\section{Summary}

Introduction. The article presents the results of a study of the activity of oxidative processes and the state of the defense systems of rats under conditions of their defeat with paracetamol and after correction with a thick extract from maitake mushrooms.

The aim of the study - to learn the effect of a thick extract of maitake mushrooms on the activity of lipid peroxidation and oxidative modification of proteins under the conditions of paracetamol hepatitis in rats.

Research Methods. The studies were carried out on the male white rats. The animals were divided into 10 groups, each of which included 6 animals. Acute hepatitis was modeled by intragastric injection of paracetamol at a dose of $1250 \mathrm{mg} / \mathrm{kg}$ once a day (for 2 days) as a suspension in a $2 \%$ starch gel solution. Correction of toxic damage was carried out with a thick extract of maitake mushrooms, which was administered intragastrically 2 hours before the introduction of paracetamol and daily after the injury at a dose of $150 \mathrm{mg} / \mathrm{kg}$ of body weight. The comparison drug "Silibor" was administered according to the same scheme as the studied extract at a dose of $20 \mathrm{mg} / \mathrm{kg}$ of animal body weight. On the 3rd, 7th and 10th days from the beginning of the lesion, the rats were euthanized with sodium barbamil. Liver homogenate and blood serum were examined. The activity of free radical oxidation processes in paracetamol hepatitis and after the introduction of corrective drugs was assessed by the activity of superoxide dismutase, catalase, the content of TBA-AP and OMP products.

Results and Discussion. An increase in the activity of free radical oxidation processes after paracetamol damage to rats is evidenced by a decrease in the activity of superoxide dismutase and catalase, an increase in the content of TBA-active products, products of oxidative modification of neutral and basic proteins in the blood serum and liver of animals. The effectiveness of the use of a thick extract of maitake mushrooms and its positive effect on the activity of lipid peroxidation and oxidative modification of proteins under conditions of paracetamol hepatitis in rats was experimentally proved.

Conclusions. The use of the investigated extract of maitake mushrooms under conditions of simulated acute hepatitis in rats led to the normalization of lipid peroxidation, oxidative modification of proteins and antioxidant protection.

KEY WORDS: maitake mushrooms; paracetamol; hepatitis; thick extract; oxidative stress; antioxidant properties.

Отримано 07.08.20

Адреса для листування: Л. С. Фіра, Тернопільський національний медичний університет імені І. Я. Горбачевського моз України, майдан Волі, 1, Тернопіль, 46001, Україна, e-mail: ludafira@ukr.net. 